\title{
Lifelong learning in the new millennium: Voices from the XV World Congress of Comparative Education Societies
}

\author{
Suzanne Majhanovich • Diane Brook Napier
}

Published online: 27 September 2014

(C) Springer Science+Business Media Dordrecht and UNESCO Institute for Lifelong Learning 2014

\section{Introduction}

The organising theme of the XV World Congress of Comparative Education Societies (WCCES), held in Buenos Aires from 24 to 28 June 2013, was "New Times, New Voices". As such, efforts were made to foreground voices of scholars and researchers from the developing world, with much success, as the report from the local Congress convenor, Norberto Fernández Lamarra below shows. The issue of "new times" and what is important for education in the new age was also the subject of many papers in the academic programme of the Congress. In times of ongoing change, where it is estimated that the average person will be involved in several career changes during his/her lifetime, where interaction with technology is essential, and where countries worldwide make it a goal for their citizens to be part of the knowledge society, lifelong learning is becoming a central concern.

This special issue of the International Review of Education (IRE) highlights features of this emerging wider landscape in education, which is by no means new, but which is garnering increasing attention globally, giving credence to the importance of extended and more complex forms of learning in multiple dimensions. It includes cases from different parts of the world on all levels of education, but focuses in particular on education for adults, literacy programmes for those who have missed out on formal education, and initiatives to develop a learning society. As the 20th century drew to a close, the previous decades of development and advancement in education brought to the fore a set of imperatives and goals for the new millennium based on what had been achieved and what lay ahead to work

S. Majhanovich $(\bowtie)$

Faculty of Education, Western University, London, ON, Canada

e-mail: smajhano@uwo.ca

D. Brook Napier

University of Georgia, Athens, GA, USA

e-mail: dnapier@uga.edu 
on in the next century. In all fields of education, there was recognition that inclusive education and access to education were integral components of overall human resources development and environmental sustainability, and that worldwide opportunity for a better life for all hinged on acquiring literacy, learning knowledge and skills, and empowerment. The goals focusing on educational development of necessity extended to dimensions of wider life in implying expansion and sustainability of universal human rights, as well as democratic processes with civic participation and better governance.

By the turn of the century, comparative education scholars were pointing to the rise in recognition of new forms of education and also the return to acknowledging previously underrated forms of education (such as vocational and technical education, and education for self-reliance which had lost status amidst the decadeslong push for formal education and mass public education). Noel McGinn and William Cummings (1997) and David Baker and Alexander Wiseman (2005) were among those who highlighted the fact that alongside a century of achievement in institutionalised mass schooling, in the next century lifelong learning, adult education and a variety of non-formal and informal types of education would play important roles in furthering development, especially in disadvantaged countries and rural areas, but also elsewhere.

"Education for All" (EFA) (UN 2007a) became a major global system of goals for expanding access to schooling and other forms of education by 2015, with annual monitoring of progress to document attainment levels and areas of need within countries and regions, and with the mid-point of 2007 highlighted in a swarm of reports and assessments. EFA was launched in March 1990 at the World Conference on Education For All in Jomtien, Thailand. In 2000, at the World Education Forum in Dakar, six areas with goals to be achieved by 2015 were identified: (1) Early childhood care and education; (2) Universal primary education; (3) Youth and adult learning needs; (4) Adult literacy; (5) Gender parity and equality in education; and (6) Quality of education. Clearly, EFA extended to all levels of conventional schooling for school-age children, but also beyond schooling into adult life and into groups in a given population which might not have had opportunities for basic education or which wished to engage in second chances at schooling as well as new forms of learning in adult life at all stages. Similarly, Goal 5 (focusing on gender parity and equality in education) targeted gender inequities worldwide, particularly to increase access to schooling for girls but also to provide for learning opportunities, literacy acquisition and empowerment for women. These contained the potential multiplier effect of improvements in many areas of human resource development such as healthcare, basic hygiene, community development and environmental sustainability as well as political empowerment and civic participation for women.

In conjunction with EFA, also in 2000, the "Millennium Development Goals" (MDGs) were launched, with a complementary set of eight goals aiming for global development in key areas: (1) Eradicate extreme poverty and hunger; (2) Achieve universal primary education; (3) Promote gender equality and empower women; (4) Reduce child mortality; (5) Improve maternal health; (6) Combat HIV/AIDS, malaria and other diseases; (7) Ensure environmental sustainability; and (8) 
Develop a global partnership for development. The Millennium Development Goals Report (UN 2007b) was a major milestone documenting the progress made in all areas in the first years of the undertaking. As with EFA, it is evident that while "primary education" is given prominent place in Goal 2, elements of lifelong learning, informal and non-formal learning and adult education have potential key roles in efforts to make progress in all of the other goals. In related undertakings, the degree of technical knowledge in countries worldwide became a major thrust of research, development and documentation. In least-developed countries in particular, the issue of technical know-how acquisition and skills development for economic growth and overall national development is also connected to the need for lifelong learning beyond school (see The Least Developed Countries Report, UN 2007c).

Next, advancing EFA and the MDGs, the United Nations Secretary-General, Ban Ki-Moon, announced the "Global Education First Initiative" (GEFI) in September 2012. "By rallying a broad spectrum of world leaders and advocates, GEFI aims to raise the political profile of education, inspire new partnerships and mobilize additional funding to deliver on the promise of Education for All" (UNESCO 2012). The Secretary-General argued that "when we put Education First, we can reduce poverty and hunger, end wasted potential - and look forward to stronger and better societies for all" (ibid.). Set up as a five-year initiative, GEFI focuses on three priority areas:

1. Put every child in school. Education is a human right. Yet advances in education have not benefited everyone equally, leaving some 57 million children out of school. Barriers to school enrolment and completion must be removed.

2. Improve the quality of learning. An estimated 250 million people are not able to read, write or count, irrespective of whether they have been to school or not. Urgent action is needed to ensure that children have the skills they need to thrive in life and work.

3. Foster global citizenship. Education must be transformative, cultivating respect for the world and each other. It should provide children with the understanding they need to cooperate in resolving the interconnected challenges of the $21 \mathrm{st}$ century.

As noted previously for EFA and the MDGs, while GEFI highlights school learning, the implication extends to learning beyond schooling if the larger goals are to be met in all of the desired areas. Collectively, these macro-systems for promoting and monitoring development in many areas also focused on the need for quality education on a wide variety of levels. Scholars in comparative education documented the complexity of "quality education", how it is defined, what forms it takes, and how it can be attained (see for instance the cases in Brook Napier 2014). Within the broad conceptions of education in the new millennium, there has also been a reinforcement of the importance of context and of contextual factors which are powerful determinants of quality in terms of the learning environment, the educational delivery process and substance (teaching and curriculum), and in terms of how quality education is conceptualised at all levels in a given country or 
system (see for instance the essays in Lee et al. 2014). Contextual factors and realities at classroom and village levels, for instance, are important considerations in weighing how education in any form can contribute to a better life for the people involved. Official policies and how they are implemented are crucial for promoting recognition of all forms of learning.

Furthermore, a more extensive consideration of diversity (in many different forms) is implicit in the broad picture painted here, since disadvantaged, disempowered and previously excluded individuals and groups deserve a chance to participate. New arenas for participation, new recognition of conventional and alternative forms of learning, and mechanisms for these to contribute to attainment of the larger goals mean that "new times" have arrived and "new voices" need to be given a hearing. Hence, in selecting a timely, relevant and appropriate theme for the XV World Congress of Comparative Education Societies, the Congress host, the Argentine Society of Comparative Studies in Education (SAECE; Societad Argentina de Estudios Comparados en Educación), identified as its Congress Theme "New Times, New Voices", and enabled a celebration of a rich array of new insights on education, learning and empowerment at all ages and stages of life and in all countries worldwide.

The XV World Congress held in Buenos Aires, Argentina, marked the first time that a World Congress was held in South America. It was the second time in Latin America overall, since the XII Congress was held in Havana, Cuba in 2004. The organisers from SAECE worked tirelessly to stage a memorable congress which will make substantial contributions to the knowledge base of comparative education in these new times. It will encourage new voices to report on educational research and systems in the Global South. Norberto Fernández Lamarra, the President of SAECE and Vice-President of the WCCES, provided his reflections on the Congress:

The XV World Congress in Buenos Aires: New voices and new times for education in the current world and in future

The XV World Congress of Comparative Education Societies, held in June 2013, has significantly advanced knowledge about education. Researchers, scholars, teachers, policy makers and government officials from more than 70 countries came together in the City of Buenos Aires to reflect on Comparative Education. This has been a novel development in the history of Argentine education. Five busy working days encompassed three Plenary Lectures and six Key Panels, nine Highlighted Panels, two Workshops and two hundred Parallel Sessions, with 1,100 individual papers and 83 joint presentations where "voices" from all over the world have met, engaged in dialogue and discussed education in these "new times".

From the outset, the Congress, hosted for the World Council of Comparative Education Societies (WCCES) by the Argentine Society of Comparative Studies in Education (SAECE) was envisaged as an opportunity to listen to innovative thinking in contemporary education. Day after day, local media as well as sources from Latin America and the rest of the world portray the difficulties facing an education system to deliver in a global, complex society. 
When designing this Comparative Education World Congress, our aim was to enhance the idea of listening to "new voices" to reflect on how "new times" are experienced. The focus on education in general and on education systems in particular, from the perspective of Comparative Education, was proposed to reflect on these new processes, which have hitherto barely been addressed. This World Congress had a wide scope and attracted a large turnout. About 1,300 papers for working sessions and over 150 panel proposals were evaluated by local and global academics and allocated to 12 sub-themes:, such as "Voices from the South", "New Perspectives on the State, the Global and the Local", "Voices of Diversity and New Forms of Educational Democratisation", "Voices from Countries/Areas in Conflict or Fragility", "Voices from Those in Adult Learning/Lifelong Learning/Nonformal Learning" among other thematic groups, where participants could present their work in extended Parallel Sessions.

One of the characteristic features of this Congress has been precisely the diversity of voices. In parallel sessions, presentations featured researchers from five continents. Besides large numbers of Argentinian and Latin American academics, there were delegates from Egypt, Rwanda, Ethiopia, Angola, the Philippines, Nepal, Mongolia, Thailand and Vietnam, among many other countries. Out of nearly 1,300 participants, 66 per cent were Latin American, 11 per cent were from North America, 10 per cent were European, 8 per cent Asian, 2.5 per cent African and 2 per cent from the Australia Pacific area. It is worth remarking there was a very strong presence from Latin America, a region where comparative studies in education have up to now not shown any remarkable development. Such ample participation acknowledged trust in the World Council of Comparative Education Societies (WCCES) and the Argentine Society of Comparative Studies in Education (SAECE) being successful in hosting the XV World Congress in the City of Buenos Aires. There was diversity in some cross-thematic Working Groups. For example, there was a session on privatisation of education with evidence-based policies from Turkey, the United States of America, Spain, Brazil and Chile. In another session on educational quality assurance, academics from Brazil, Japan, Thailand and Mexico shared their presentations with audiences. The diversity of voices can be seen in the range of panels organised by scholars from a wide array of countries and on a wide range of issues. Let me give some examples. Comparative analysis of transformations in contemporary education was offered in papers from South Africa, Kazakhstan, the United Kingdom and Cyprus. The second half of the double Panel on "Current Changes in the Academic Profession Worldwide" included experts from Portugal, Argentina and China; another Panel on "International Large-scale Assessments and the Construction of 'Reference Societies'", featured researchers from Australia, Germany and Portugal, and the Panel entitled "Adolescent Girls' Leadership Development: Sharing Care's Approach to Empowerment and the Impact it has on Educational Outcomes" had speakers from Yemen, Bangladesh and Malawi. 
Besides individual papers or joint presentations in parallel sessions, the Organizing Committee strove to showcase diversity of voices and ideas in key panels and lectures. The World Congress included three Keynote Lectures: Argentine academic Bernardo Kliksberg on "Development and Education for New Times", Spain's Miguel Pereyra addressed the audience on his diachronic perspective in the study of educational systems, and Sondra Hale, anthropologist and specialist on social movements in Africa, lectured on postcolonialism and social movements. There was a Key Panel on revisiting the Delors Report, one of the landmarks in 20th-century education, organised jointly by the UNESCO Chair of Comparative Education at the University of Hong Kong and UNESCO Education Research and Foresight; another panel on the revolutionary thinking of Paulo Freire. Investment in education and equity and Democratisation of educational systems were sub-themes which had a prominent place on the Congress agenda. Another key panel was devoted to institutional reshaping in the field of Comparative Education, placing emphasis on the role of new societies of Comparative Education with members of AFRICE (from Africa), SOMEC (from Mexico), and CESA (from Asia). ${ }^{1}$ Also, Jürgen Schriever chaired the Panel labelled "World Culture ReContextualized", with colleagues from the USA, Sweden and Israel.

"Fifty Years After Angicos", the Panel devoted to Paulo Freire, deserves close attention. It was specially organised to commemorate the 50th anniversary of one of Freire's first experiences in literacy training, at a small village in Brazil called Angicos. Chaired by Clementina Acedo (UNESCO IBE), this Panel included Anne Hickling-Hudson (University of Queensland, Australia), Nelly Stromquist (University of Maryland) as well as Carlos Alberto Torres (UCLA, USA and incoming President of WCCES), who delivered the panel introduction in his presentation. The Academic Committee of the XV World Congress also decided to highlight some panels among all the proposals received, some arising from different world regions: Assessment in Latin America, Supranational Policies in Europe, US-Canadian Perspectives on Comparative Education, Visions and Voices of Africa, and Comparative Education in Asia-Pacific. Others were developed on current strands in the educational field, such as Changes in the Academic Profession and ICT and Educational Innovation, which have been forums for reflection. This has been a suitable environment to listen to a diversity of voices: colleagues from China, Taiwan, Australia and Japan shared their thinking on Comparative Education in Asia and the Pacific Rim, while colleagues from South Africa, Burundi, Egypt and Nigeria lectured on Comparative Education in Africa. Within the framework of the XV World Congress, there were also two Workshops, one about the Information System on Latin American Education Trends (SITEAL) and another on production and dissemination of knowledge

\footnotetext{
1 AFRICE stands for Africa For Research in Comparative Education Society; SOMEC stands for Sociedad Mexicana de Educación Comparada and CESA stands for Comparative Education Society of Asia.
} 
in the field of Comparative Education, with a focus on journals and specialist publications.

I wish to stress an important, highly significant development which occurred in the WCCES General Assembly and Closing Ceremonies of the Congress. The WCCES General Assembly voted unanimously in support of a "ProUNESCO Statement", which denounces some UNESCO Member States withholding payment of their dues to reject decisions of UNESCO's General Conference. This situation affects UNESCO's capacity to accomplish its mission and "introduces a pressure mechanism which alters the nature of democratic decision-making processes". Therefore, the WCCES General Assembly formally requested that countries desist from these practices which have a negative impact on educational systems on a global scale. ${ }^{2}$

The XV World Congress has been a forum to reflect on contemporary education. Every academic activity has allowed for exchanges among prestigious researchers and new scholars from widely different backgrounds: Latin American, North American, European, African or Asian, but all with a shared interest: talking to "new voices". The XV World Congress has been a forum to listen to rising voices in diverse world regions. We have tried to show that Comparative Education and comparative studies in education are core academic tools to analyse new educational issues in a world where there is vertiginous change in society, politics, science and technology.

Finally, I wish to emphasise the significant cooperation received from governments, universities, international and national organisations, colleagues from Argentina and abroad. SAECE and the Organizing Committee would have been unable to host this World Congress without such strong cooperation.

In this respect, it may be considered that the aim we set when bidding to host the XV World Congress has been achieved to a great extent. As stated in my Inaugural Address, ${ }^{3}$ it is hoped that the papers submitted and the debates which took place will have enabled progress towards democratic, equitable education which prioritises the needs of the oppressed, the poor and the underprivileged. Education which fosters cohesion and social integration strengthens strategic values to form a multicultural society; education which engages in free participation of citizens who are open to knowledge, science and new technologies; education where policies are implemented through consensus-making processes; in fact, policies which give a voice to those who have been marginalised, hitherto unheard, and will lead to achievement of gender equality.

To that end, new and truly innovative models are needed: organisational, pedagogical, curricular and didactic models. Education has to be pertinent to social needs - particularly of those people who have been marginalised up to now - and thus shape new managerial models of participation which are open

\footnotetext{
2 The statement is available online at http://www.wcces.com/WCCES-Declaracion-pro-UNESCO.pdf [acessed 26 August 2014].

3 The full Inaugural Address is available at www.saece.org.ar.
} 
and efficient, not just in terms of the world economy and production but which also, most especially, pertain to the common good.

Norberto Fernández Lamarra ${ }^{4}$

\section{The Congress papers featured in this special issue}

Although the XV World Congress addressed many aspects related to Comparative Education in our New Times, the papers selected for this special issue are ones which address various elements of lifelong learning and how the concept has evolved in the context of the new millennium. The first three papers, by Wing On Lee, Shibao Guo, and Suwithida Charungkaittikul and John Henschke, are very much concerned with lifelong learning in the 21 st century and how it has evolved from lifelong education to a phenomenon suited to a century of rapid change and development and focused on a knowledge economy. Their papers also discuss the implications of equity in EFA and lifelong learning. The next two papers, by Anne Hickling-Hudson and Nelly Stromquist, discuss adult and informal education in relation to the work of Paulo Freire on literacy and emancipation from class oppression. The final paper, by Bob Boughton and Deborah Durnan, provides an interesting case study of the Cuban literacy programme "Yo, Sí Puedo" as applied in Timor-Leste and in an Aboriginal community in Australia.

Wing On Lee, in "Lifelong learning and learning to learn: An enabler of new voices for the new times" expanded upon his Presidential address at the XV World Congress to reflect on how the "new times" in the 21 st century have had an impact on the concept of lifelong learning. He connects the conference theme of "voice" to the need in the world of today to engage the voices of those who have been ignored and marginalised. He discusses the various possibilities of lifelong learning as a way to accomplish that.

He draws on the report of the Organisation for Economic Co-operation and Development (OECD) entitled Schooling for Tomorrow (OECD 2001) to illustrate the complex interaction of various educational scenarios, from bureaucratic school systems as they confront the "market model" of education, through schools as core social centres and focused learning organisations (to meet the needs of the market economy) to the decentralised situation where learner networks stand alongside the more traditional bureaucratic centralised school systems - in short, how in our new times formal and non-formal education co-exist.

Lee discusses the various implications of lifelong learning, declaring it to be an emerging concept. He notes that in the past the term was "lifelong education" and was associated with institutions providing courses and programmes which they deemed to be appropriate. In the new times of the 21 st century, the term has evolved to "lifelong learning", which focuses on individuals' participation in knowledge building to meet the needs of the changing economy and society. He connects this to the recommendations of the Delors Report of how to meet the demands of the $21 \mathrm{st}$

\footnotetext{
${ }_{4}$ The translation of this report was prepared by Prof. Jessica Bohan (SAECE, Argentina), special thanks to her.
} 
century by recognising the four pillars of learning: learning to know, learning to do, learning to live together and learning to be (Delors et al. 1996). Now it is institutions who respond to the requirements of society and the market economy by providing often informal programmes outside the regular academic canon. Eventually these professional courses gain credibility and provide qualification certificates for those requiring the skills to be part of the new economy.

Lee sees the contribution of lifelong learning institutions as "forming a bridge between market needs and academia". The implication is that universities have begun to engage in corporatisation to meet the needs of the global market, a trend many would regard with alarm. Nevertheless, Lee sees these developments in lifelong learning as a positive force which can empower those whose voices previously were not heard. He calls for a seamless linkage between formal and informal education that will make lifelong learning an "enabler of voice" of all those actively involved in society.

In "Revisioning Education for All in the age of migration: Global challenges and opportunities for lifelong learning", Shibao Guo considers implications of the EFA movement as well as lifelong learning in the context of two very different locales, China and Canada. He presents two cases, one of migrant children in China and their plight in accessing basic education; the other of well-educated immigrants in Canada who face obstacles in being accepted into the workplace with jobs comparable to their qualifications.

In the case of China, he questions whether the policy which is supposed to ensure education for all school-aged children is working, given the exclusion from public education of many migrant children whose parents have moved from the less developed interior of China to the economically vibrant cities in the East. Because the Chinese migrants are not considered to be permanent residents of the coastal cities where they have found employment, their children are often denied access to schools since they lack the required documents to allow them to sit entrance exams, or are refused admission to schools concerned about lowered academic standards. This Chinese situation is deemed "a case of maldistribution".

In the Canadian context, Guo decries the fact that many well-qualified immigrants cannot get recognition of their qualification certificates. He describes a "triple glass effect" which immigrants face: the glass gate which denies immigrants entrance into the professions; the glass door by which employers in high-wage endeavours block immigrants' access because of their lack of Canadian experience, and the glass ceiling which prevents immigrants from moving up into managerial positions.

Guo based his paper on the theory of recognitive justice in terms of EFA and lifelong learning in the hopes that Chinese migrant children will eventually be given access to quality schooling, and that adult immigrants in Canada will be able to take part in inclusive lifelong learning which will eventually permit them equal status with native-born, comparably educated Canadians. Guo hopes that in the post-2015 revision of EFA, attention will be paid to the marginalised to address the issue of social justice and equity for all.

In "Strategies for developing a sustainable learning society: An analysis of lifelong learning in Thailand", Suwithida Charungkaittikul and John Henschke 
acknowledge the importance of the learning/knowledge society in the new millennium, and consider the case of Thailand, which has endeavoured to make the whole country into a learning society. They discuss several cases within Thailand where progress has been made in this immense learning project, and also furnish guidelines for the development of a sustainable learning society. Elsewhere, Charungkaittikul (2011) describes a learning society as one "comprised of learners, learning providers, learning resources, wisdom/knowledge, lifelong learning activities, learning climates, learning networks, knowledge management and learning organisations." In Thailand, lifelong learning is mandated by law, and the official Office of Non-formal and Informal Education (ONIE) has played a key role in the promotion of lifelong learning and the creation of a learning society. This paper outlines learning society best practices of five communities which have seriously engaged in the project of creating a learning society. It is interesting that among other qualities which will foster a learning society in the 21st century, the Thai learning society recognises the value of local wisdom.

While the authors admit that Thailand cannot currently be universally declared a learning society, many parts of the country have joined the ambitious project and they estimate that by 2018 many Thai people will be engaged in quality lifelong learning.

The authors note that in Thailand, too, the term "lifelong education" has evolved into "lifelong learning", which involves educational activities beyond those overseen by the Ministry of Education, and includes participation of the "private sector, mass media, community groups and the population at large". Thus the evolution of lifelong learning in Thailand mirrors the situation described by Wing On Lee when he refers to the scenarios described in the 2001 OECD report, and also calls for a seamless linkage between formal and informal education.

The XV World Congress took place in Latin America in 2013, 50 years after the philosopher and educator Paulo Freire had set up literacy training for illiterate adults in Angicos, Brazil, and as such provided an ideal locale where Freire's legacy could be reflected upon and celebrated. Two papers drawn from a Special Panel on Freire are included in this special issue. They highlight Freire's influence in education, particularly in the area of adult education and non-formal learning for literacy development.

The first of these papers, "Striving for a better world: Lessons from Freire in Grenada, Jamaica and Australia", by Anne Hickling-Hudson, provides excellent examples of the way Freirean approaches have evolved in three very different settings, promoting not only literacy development, but also supporting the struggle for a better, socially more equitable life.

The author had first-hand experience working with Freire as she served as one of the facilitators in a 1980 seminar designed to develop strategies for changing education in Grenada. The seminar, which, contrary to traditional pedagogical practice, did not use "top-down" methods, instead required participants to develop the content for the new curriculum based on their own experiences and perceptions of what was needed to improve education. Although much of the promise for positive change was undermined by the political unrest and the 1983 invasion of Grenada, Hickling-Hudson still reckons that "some of the educational changes 
endured, and have provided the basis for people to continue striving for a better society". An important outcome of the seminar was the process of conscientisation which the participants underwent.

Hickling-Hudson's second case involves the Area Youth Foundation in Jamaica (AYF). The AYF works with marginalised youth encouraging artistic expression in the form of drama, art, music, film or printed texts. Following Freirean approaches, the actors enter into a dialogue with their audience to work out solutions to the issues raised in the presentation - issues relevant to their daily lives.

The final case she presents involves curriculum development of the Honey Ant Readers in an indigenous community in Australia. The curriculum developed in this community follows the Freirean principles of "conscientisation, co-learning, codevelopment of the materials and praxis in terms of how they are tried out and improved". The "Honey-Ant Reader" project has helped children develop literacy and numeracy skills through reading the materials based on their own context. In addition, adults have also benefited both by reading the materials with the children and by translating them into their indigenous language.

Hickling-Hudson shows the application of Freirean pedagogy in the three cases where knowledge pertinent to the communities is created as opposed to the traditional "banking" style of education where a pre-conceived curriculum reflecting colonial values and norms is imposed on the learners.

In "Freire, literacy, and emancipatory gender learning", Nelly Stromquist reflects on three issues related to Freire's work: gender emancipation, adult literacy development and how long it actually takes to become literate, and finally the use of culture or study circles.

Although Paulo Freire was not generally considered to be concerned with feminism and gender issues, his association with critical pedagogy in the classroom, with the imbalances of power in society and oppression arising from class differences, has nevertheless certainly informed the feminist movement. Stromquist notes that although the term "empowerment" does not appear in Freire's works, it is related to conscientisation or awareness of class inequalities which feminists have embraced in their struggles against patriarchy.

Stromquist also comments on the Angicos literacy programme's claims that adults could become literate after only 40 days. She questions whether this is actually possible, and has reservations about the extent of literacy gained and the state of (il)literacy of those first Angicos participants. She argues that one must distinguish among various kinds of illiteracy, considering people who never attended school; people who may have attended school for several years but who have forgotten anything they learned there; as well as those with limited levels of literacy, or those with learning problems. Stromquist is sceptical about the alleged success of the 40-day Angicos programme and recommends that in order to assess adult literacy, we must pay more attention to the context in which adult illiterates live and understand that the process of literacy development is "resourceintensive". She mentions other literacy programmes, like "Yo, Sí Puedo" (discussed in the final article of this special issue), which require far more time to complete, are more structured and also provide follow-up maintenance programmes after the initial fairly modest level of literacy has been attained by the participants. 
Stromquist's third issue relates to Freire's culture circles and the necessity of a dialogue for learning to take place. She notes that in fact the Folk Schools in Denmark, Gramsci's study circles as well as the Frankfurt School's emphasis on the importance of dialogue all predate Freire's culture circles. This places him in a continuum and solid tradition of emancipatory pedagogical praxis. She also notes that the consciousness-raising (CR) employed by feminists was developed totally independently to Freire's work, but that it clearly belongs in the same genre of conscientisation.

As Stromquist concludes, Freire has made enormous contributions to adult education and has worked in parallel with other movements, all of which contribute to a deeper understanding of literacy.

The final paper of this collection, “Cuba's 'Yes I Can' mass adult literacy campaign model in Timor-Leste and Aboriginal Australia: A comparative study", by Bob Boughton and Deborah Durnan, presents the case study of a very successful literacy programme in two quite different contexts. In the first case, the Cubandeveloped programme was part of a national literacy campaign in the new nation of Timor-Leste; the second evaluated "Yo, Sí Puedo" as a pilot project in one Aboriginal community in Australia.

The authors provide an overview of past mass literacy campaigns which were popular in developing countries in the mid-20th century. The programmes were often supported by socialist countries like Cuba, China and Russia, and as such were opposed by the World Bank, the United States as well as by several United Nations agencies which urged governments to focus on national school programmes, often with curricula borrowed from the developed North, and to leave informal literacy programmes to non-governmental organisations (NGOs). With the proclamation of the United Nations Literacy Decade (2003-2012), mass literacy campaigns delivered in non-formal programmes found favour again. "Yo, Sí Puedo" is one of several very successful mass literacy campaigns developed by Cuba and was prepared with a view to sharing the programme with developing countries from the Global South.

Boughton and Durnan provide details of the "Yo, Sí Puedo" programme, including details on how the lessons are constructed and delivered. The programme contains elements most would associate with traditional reading programmes such as phonics instruction, letter recognition and structural build-up from words to phrases to sentences and finally paragraphs. However, what makes the programme particularly popular in the Global South is the fact that the lessons are contextualised to fit local conditions and are held under the guidance of Cuban advisers. Moreover, learning materials are constructed locally in local languages. In this way, the "Yo, Sí Puedo" programme operates in the spirit of Freirean pedagogy despite the structural nature of the lessons.

The authors spent extensive time observing and assessing the "Yo, Sí Puedo" programme in both Timor-Leste and in the Aboriginal community in Australia. They are cautiously optimistic about the programme's potential for developing literacy, but recommend more longitudinal studies to determine the sustainability of the literacy learned in the programme. Thus they are in agreement with Stromquist, who reminds us that one series of literacy lessons may not translate into long-term 
gains unless the resources are available and follow-up maintenance programmes are in place for the adult learners.

\section{Final words}

Overall, the six papers which comprise this special issue provide insights into the evolution of lifelong learning, as well as adult and informal education in the new times of the 21st century and how these types of education respond to major United Nations initiatives such as Education for All (EFA), the Millennium Development Goals (MDGs) and new Global Education Initiatives such as the Global Education First Initiative (GEFI). While commemorating the XV World Congress, whose central theme, "New Times, New Voices: Comparative Perspectives for Education" spoke to the advancements of the past century but even more to the dawning of the new era in education and comparative education, these articles illustrate new landscapes in education.

\section{References}

Baker, D. P., \& Wiseman, A. (Eds.). (2005). International perspectives on education and society. Amsterdam: Elsevier.

Brook Napier, D. (Ed.). (2014). Qualities of education in a globalised world. Comparative Education: A Diversity of Voices, Vol. 29. Vol. V in the post WCCES Istanbul World Congress 2010 Series. Rotterdam: Sense Publishers.

Charungkaittikul, S. (2011). The scenario of a learning society model toward promoting a positive paradigm shift for communities. International Journal of Adult Vocational Education and Technology [IJAVET], 2(3), 30-34.

Delors, J., et al. (1996). Learning: The Treasure Within. Report to UNESCO of the International Commission on Education for the Twenty-First Century. Paris: UNESCO.

Lee, W. O., Napier, D. B., \& Manzon, M. (2014). Does context still matter? The dialectics of comparative education. Asia Pacific Journal of Education, 34(2), 139-152.

McGinn, N. F., \& Cummings, W. K. (1997). Introduction. In W. K. Cummings \& N. F. McGinn (Eds.), International handbook of education and development: Preparing schools, students and nations for the twenty-first century. Exeter: Pergamon Press.

OECD (Organisation for Economic Co-operation and Development). (2001). Education policy analysis. Paris: OECD.

UN (United Nations). (2007a). Education for All by 2015: Will we make it? EFA Global Monitoring Report 2008. Paris: UNESCO and Oxford University Press.

UN (United Nations). (2007b). Millennium Development Goals Report. New York: UN.

UN (United Nations). (2007c). The least developed countries report 2007: Knowledge, technological learning and innovation for development. New York: UN.

UNESCO. (2012). Global Education First Initiative: The UN Secretary-General's Global Initiative on Education. Paris: UNESCO. Accessed 30 Jan 2014 from http://www.unesco.org/new/en/education/ global-education-first-initiative-gefi/.

\section{The authors}

Suzanne Majhanovich PhD, is Professor Emerita and Adjunct Research Professor at the Faculty of Education, the Western University in London, Canada. Her research interests include comparative and 
international education, language acquisition and second language teaching and learning. She is the coeditor of Comparative and Global Pedagogies: Equity, Access and Democracy in Education (Springer, 2008), and Living Together: Education and Intercultural Dialogue (Springer, 2009) among other publications. She currently chairs the Standing Committee for Publications of the World Council of Comparative Education Societies (WCCES), is a former President of the Comparative and International Education Society of Canada, and the former editor of the journal Canadian and International Education.

Diane Brook Napier is a professor retired from the faculty in the College of Education at the University of Georgia, specialising in Comparative and International Education, and a member of the UGA Institute of African Studies. She was born and raised in South Africa, where she received her undergraduate education. She is a naturalised American citizen, now residing in the United States, where she completed her graduate education. Her research and teaching specialties focus on post-colonial educational reform and democratic transformation policies and their implementation. She has conducted field research on these issues most extensively in South Africa but also in other sub-Saharan African states (including Namibia, Botswana, Zambia, Zimbabwe, Somalia, Kenya, and DRCongo) and also in Costa Rica, Cuba and the United Arab Emirates. Her research focuses specifically on issues of globalisation of education, reform policy-practice and implementation, race and deracialisation, ideology, language, justice/injustice, human resources development (in education, health, housing, water supply, labour), also on migrant and refugee issues, environmental issues, and teacher education implications. She has published widely on these topics in refereed journals and in collections of research. Recent publications include Interculturalism, Society and Education (co-edited with G. Pampanini and F. Adly, 2011); Education, Dominance \& Identity (co-edited with S. Majhanovich, 2013), Qualities of Education in a Globalised World (2014) and Does context still matter? The dialectics of comparative education (introductory article co-authored with special issue co-editors W. O. Lee, and M. Manzon, Asia Pacific Journal of Education 34(2), 139-152). Forthcoming: International Perspectives on Race and Racism: Historical and Contemporary Considerations in Education and Society (2014/15). She is currently Secretary-General of the World Council of Comparative Education Societies. 